\title{
Multi-Point Covalent Immobilization of Enzymes on Glyoxyl Agarose with Minimal Physico-Chemical Modification: Stabilization of Industrial Enzymes
}

\author{
Fernando López-Gallego, Gloria Fernandez-Lorente, Javier Rocha-Martín, \\ Juan M. Bolivar, Cesar Mateo, and Jose M. Guisan
}

\begin{abstract}
Stabilization of enzymes via immobilization techniques is a valuable approach in order to convert a necessary protocol (immobilization) into a very interesting tool to improve key enzyme properties (stabilization). Multipoint covalent attachment of each immobilized enzyme molecule may promote a very interesting stabilizing effect. The relative distances among all enzyme residues involved in immobilization have to remain unaltered during any conformational change induced by any distorting agent. Amino groups are very interesting nucleophiles placed on protein surfaces. The immobilization of enzyme through the region having the highest amount of amino groups (Lys residues) is key for a successful stabilization. Glyoxyl groups are small aliphatic aldehydes that form very unstable Schiff's bases with amino groups, and they do not seem to be useful for enzyme immobilization at neutral $\mathrm{pH}$. However, under alkaline conditions, glyoxyl supports are able to immobilize enzymes via a first multipoint covalent immobilization through the region having the highest amount of lysine groups. Activation of supports with a high surface density of glyoxyl groups and the performance of very intense enzyme-support multipoint covalent attachments are here described.
\end{abstract}

Key words Enzyme stabilization, Over-stabilization of aminated enzymes, Variables that control stabilization

1 Introduction

The low stability of most of enzymes strongly limits their implementation as industrial catalysts. The possibility of improvingtheir stability during the development of necessary immobilization techniques is a quite interesting approach [1-3]. The most popular and most effective approach is the immobilization of enzymes by multipoint covalent attachment on highly activated supports [4, 5]. When an enzyme becomes immobilized through many surface residues on a rigid support through very short spacer arms important stabilizing effects may be achieved. Now, the relative 


\section{GENERAL STRATEGY FOR STABILIZATION OF ENZYMES USING MULTIPOINT COVALENT IMMOBILIZATION}

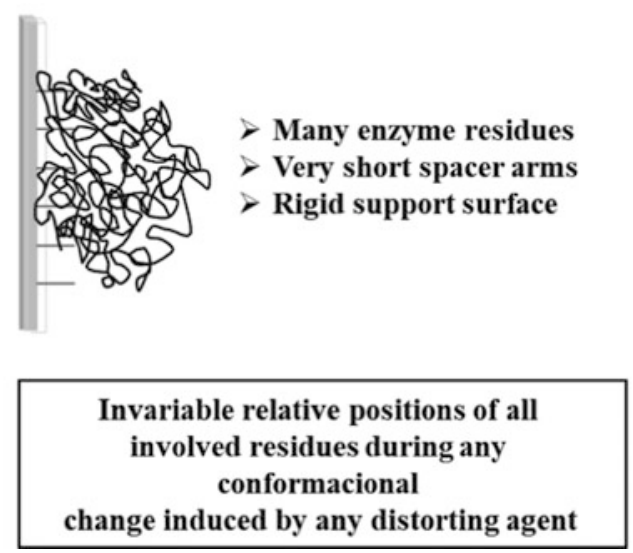

Fig. 1 A general strategy for enzyme stabilization

distances among all the residues involved in multipoint immobilization have to remain unaltered during any conformational change induced by any distorting agent. This idea is relatively simple, but the main problem is the achievement of such very intense enzymesupport multipoint covalent attachments (Fig. 1).

The most popular and conventional immobilization protocols are able to promote very fast enzyme immobilizations, through their amino groups, at neutral $\mathrm{pH}$. Under this condition, the amino terminal residue ( $\mathrm{pK}$ around 7.5 ) is thousand times more reactive than lysine residues on the enzyme surface ( $\mathrm{pK}$ around 10.5). In this way conventional immobilization (CNBr-activated sepharose, glutaraldehyde-activated supports, N-hydroxysuccinimide, etc.) occurs via the amino terminus instead, although the region with the highest amount of Lys residues would be more suitable for protein stabilization. In addition to that, conventional activation protocols utilize unstable reactive groups, and they cannot be incubated under alkaline conditions in order to favor a certain additional multipoint attachment between the support and Lys residues placed in the vicinity of the amino terminal residue. In general, conventional immobilization of enzymes is not very useful to get intense multipoint covalent immobilizations (Fig. 2).

The best solution for this problem would be finding a nonconventional immobilization protocol capable of direct immobilization of enzymes through the region having the highest amount of Lys residues. For several years now our research group has reached very good stabilization protocols for industrial enzymes by using supports activated with glyoxyl groups, aldehyde groups secluded from the support surface through very short spacer arms (Support-O- 


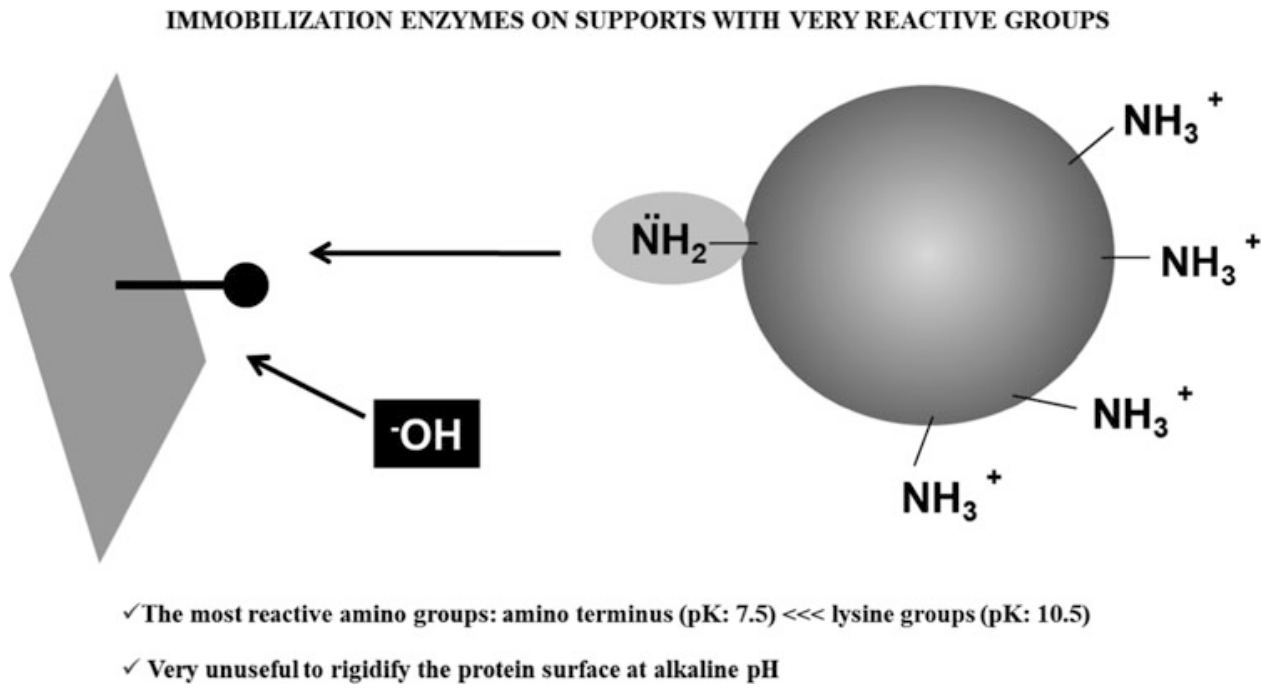

Fig. 2 Conventional immobilization protocols

VERY POORLY REACTIVE GROUPS

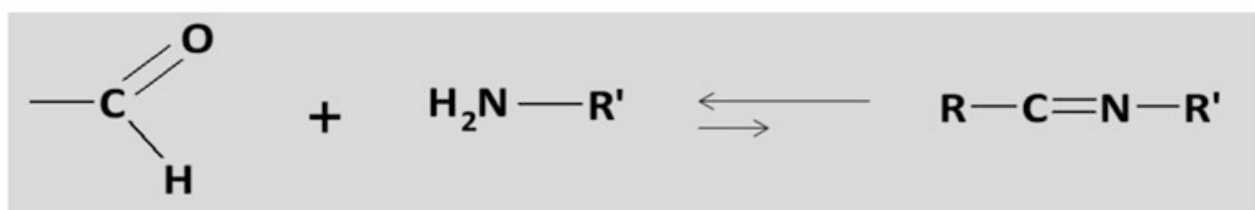

Very unstable Schiff's bases

These groups are not suitable for producing covalent links between enzyme and support at neutral pH. Nevertheless, they can be converted in the best reactive groups for protein immobilization/stabilization.

Fig. 3 Poorly reactive groups may be suitable for stabilization strategies

$\mathrm{CH}_{2}-\mathrm{CHO}$ ) [6-21]. These supports are not useful for immobilization of enzymes at neutral $\mathrm{pH}$ because the formation of a unique glyoxyl-amino attachment promotes the formation of a very unstable Schiff's base and hence monomeric enzymes with a unique amino terminus are not able to become immobilized even on very highly activated glyoxyl supports (Fig. 3).

Immobilization is also impossible under alkaline conditions (where Lys are reactive) on poorly activated supports. Again, a unique enzyme-support attachment is not able to immobilize the enzyme. On the contrary, the combination of alkaline conditions (e.g., $\mathrm{pH} 10$ ) and very highly activated supports promotes a very rapid and irreversible immobilization. These results clearly 
demonstrated that this latter immobilization occurs via a first multipoint covalent attachment through the enzyme region having the highest amount of Lys residues. Logically, this region is the most suitable for a further intense multipoint covalent immobilization. A number of other additional results also claim for this immobilization protocol, and they have been extensively reported and commented in literature [22]. At neutral $\mathrm{pH}$, the amino terminus residue is 1000-fold more reactive than Lys groups but using a nonconventional protocol, under alkaline conditions, the immobilization has been directed through the region having the highest amount of Lys residues on the enzyme surface (Fig. 4).

After this first multipoint immobilization event, we may let the enzyme-support conjugate to perform an additional intramolecular reaction in which new amino groups from the enzyme surface next to the support can be aligned with new glyoxyl groups to react in order to get a more intense multipoint attachment (Fig. 5). This additional incubation has to be long (several hours after immobilization), and it occurs better at moderately high temperatures (for example, room temperature) as the vibrations of the enzyme surface are more intense and favor a more intense lysine-glyoxyl alignment and further attachment [22, 23].

\section{FIRST IMMOBILIZATION BETWEEN ENZYME AND GLYOXYL SUPPORT}
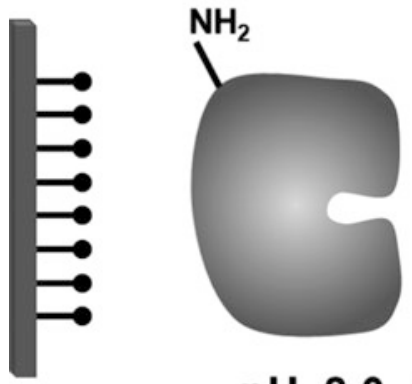

pH 8.0 (NO)

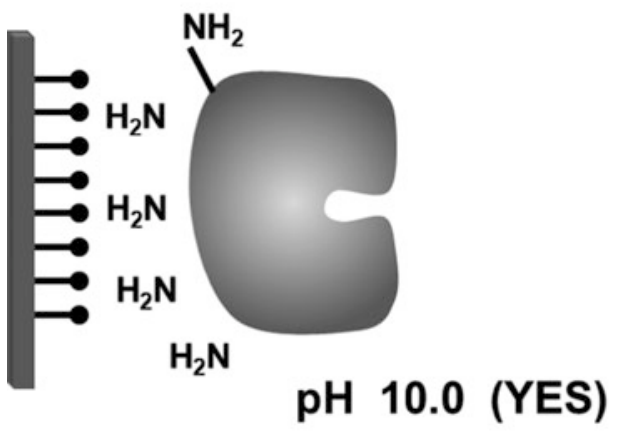

Fig. 4 Some special features of glyoxyl supports
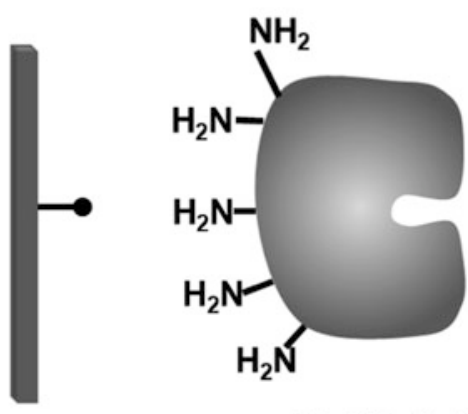

pH 10.0 (NO)

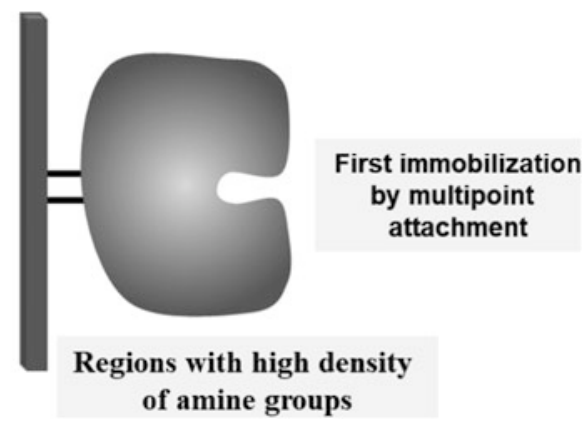


THE PROCESS OF MULTI-INTERACTION BETWEEN ENZYME AND SUPPORT

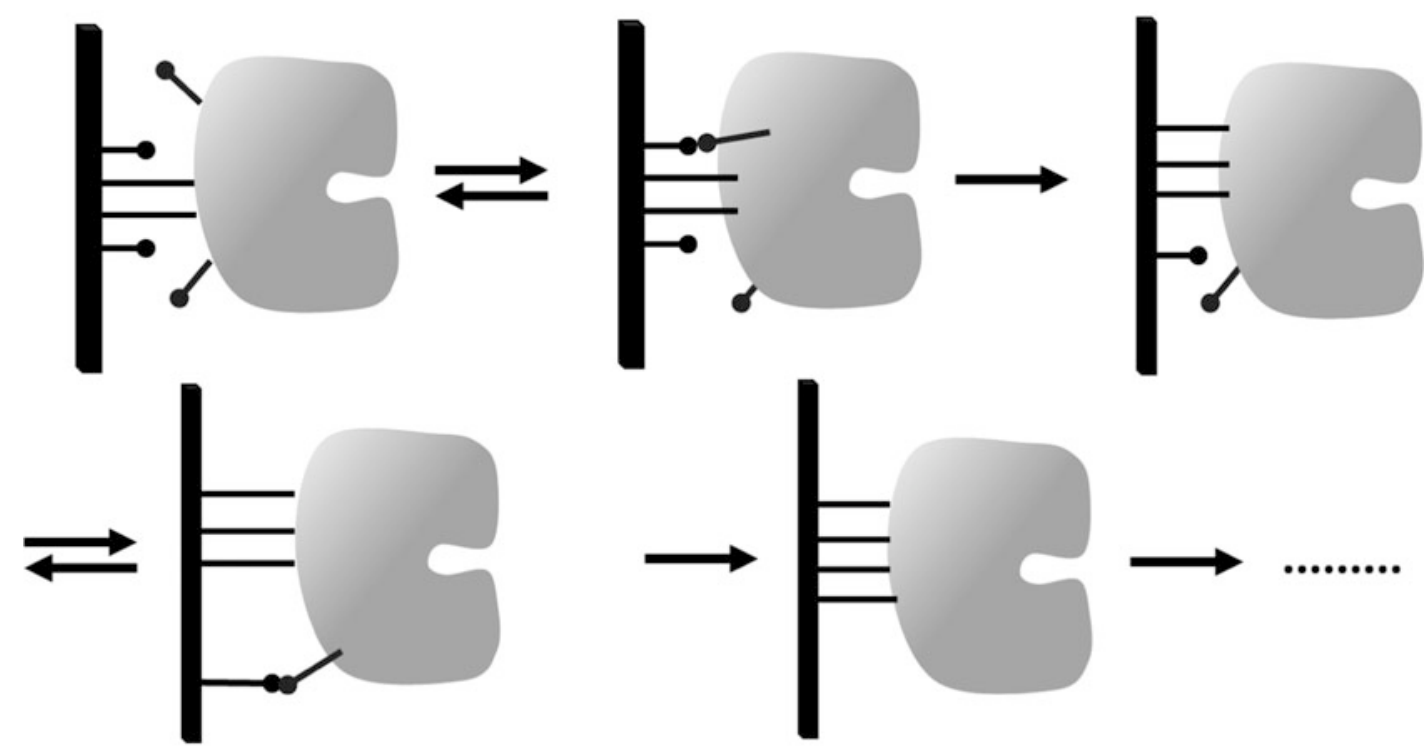

Time up to $\mathbf{2 4}$ hours after the first immobilization Temperature $\left(25^{\circ} \mathrm{C} \gg 4^{\circ} \mathrm{C}\right)$

Fig. 5 The mechanism of multipoint covalent immobilization

The end of the enzyme-support multi-interaction is performed via a very mild borohydride reduction of the derivatives (Fig. 6). In this way, Schiff's bases between amino groups and glyoxyl ones are converted into secondary amino bond and the remaining glyoxyl groups are converted into inert and hydrophilic hydroxyl groups. In this way, the chemical and physical modification of the enzyme surface will be minimal in spite of a very intense multipoint covalent attachment [22].

Glyoxyl groups, which are not useful to immobilize enzyme at $\mathrm{pH}$ 7.0, have a set of ideal properties for enzyme immobilization by multipoint attachment though. These properties are summarized in Fig. 7 [22].

In addition to that, supports with highly activated large areas (for example, agarose gels) seem to be optimal for the stabilization of the enzymes by multipoint covalent immobilization.

The enzyme support geometric congruence is very high and the density of active groups is very high. This support has also a very large density of reactive groups. For example, we can prepare agarose supports having 40-80 glyoxyl residues per immobilized enzyme molecule (Fig. 8).

Many industrial enzymes have been highly stabilized in our laboratory by multipoint covalent attachment on glyoxyl supports. In most cases the loss of catalytic activity after immobilization was

In most cases the loss of catalytic activity after immobilization was 
END-POINT OF ENZYME-SUPPORT MULTI-INTERACTION
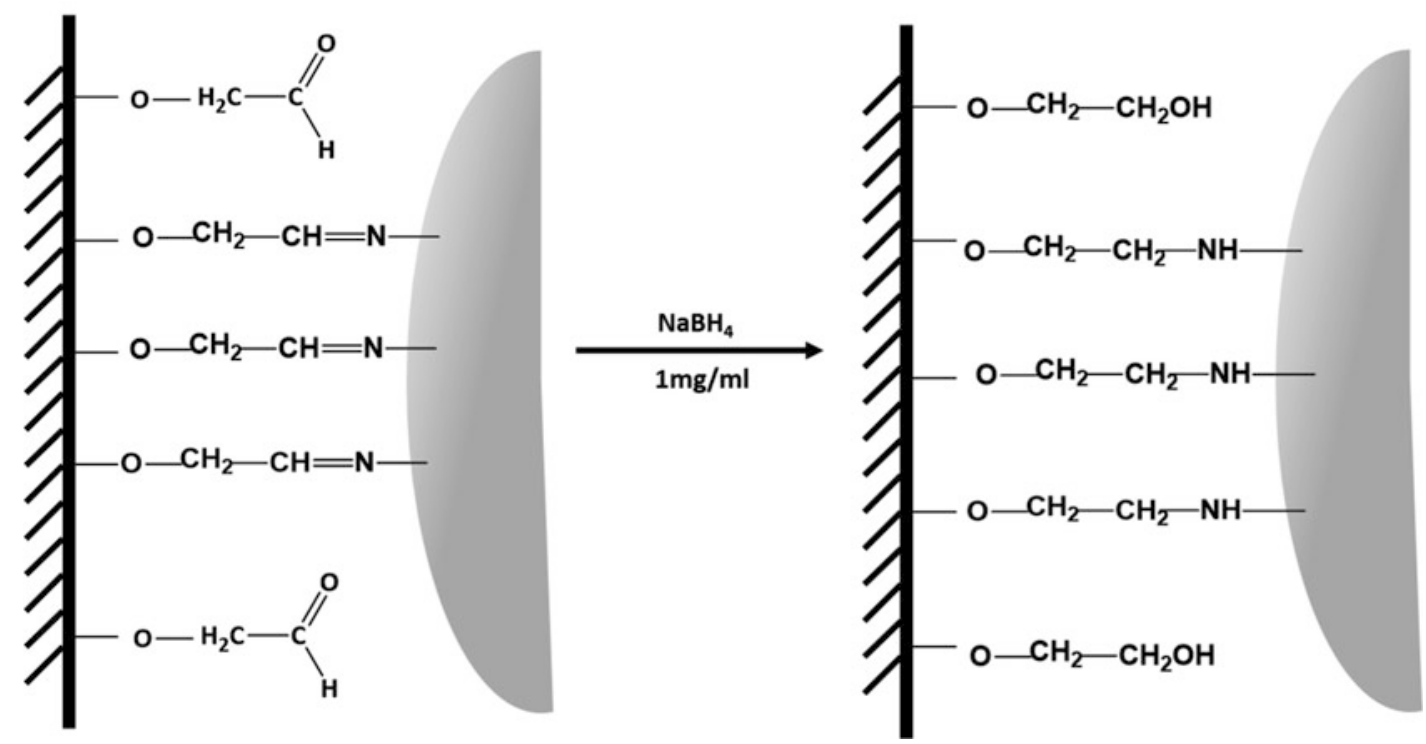

Fig. 6 End-point of multipoint covalent immobilization

\section{GLYOXYL GROUPS: SUPPORT-O- $\mathrm{CH}_{2}-\mathrm{CHO}$}

- Very stable under alkaline conditions

- Very close to the support surface

- First immobilization at $\mathrm{pH} 10$ is a multipoint covalent attachment

- Absence of steric hindrances for intramolecular reactions

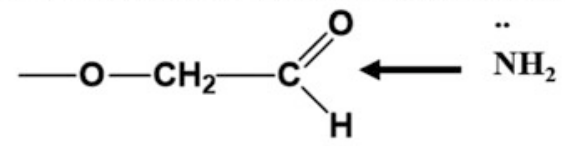

- Minimal chemical modification of the enzyme

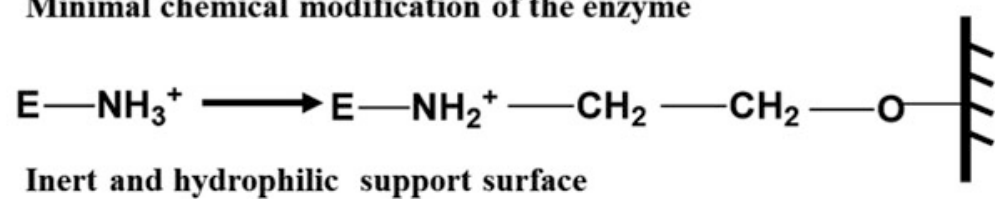

Fig. 7 Excellent properties of glyoxyl supports for multipoint covalent immobilization

very low (between 10 and 50\%), and the stabilization factors were very high (higher than 1000-fold) [6-21] (Table 1). Moreover, these factors were calculated by comparing one-point with multi- point immobilizations, and therefore they represent the true 3D stabilization of the enzyme against distorting agents. 


\section{GLYOXIL-AGAROSE SUPPORTS FOR ENZYME STABILIZATION}

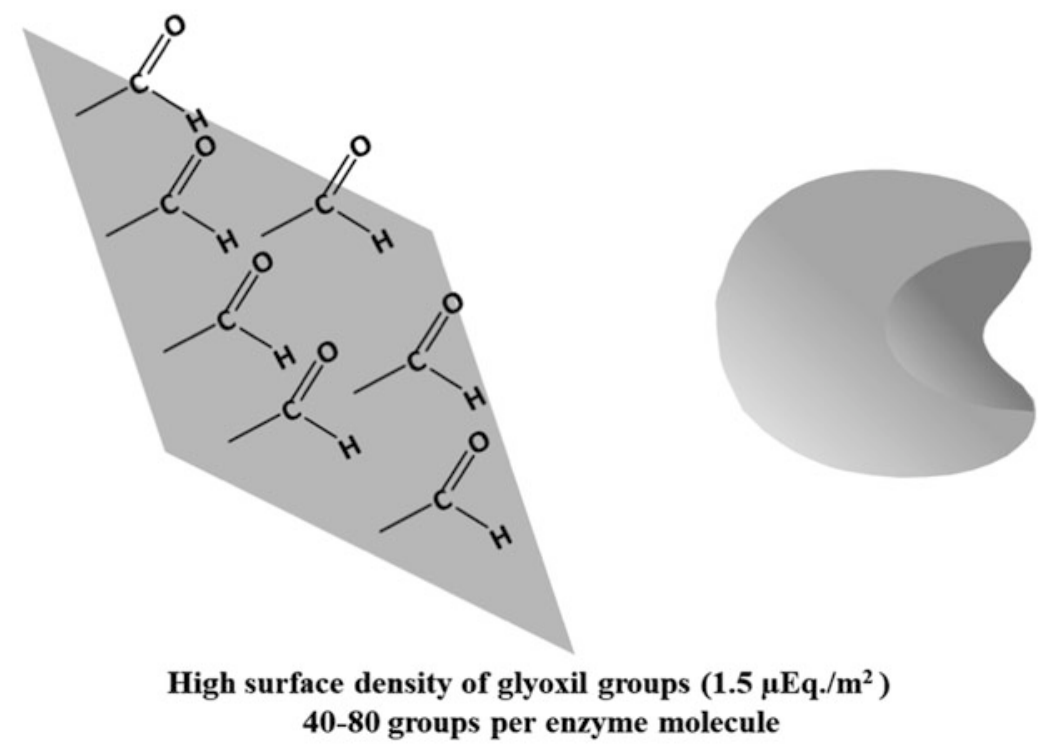

- Supports constituted by large surfaces with a very high activation degree

Fig. 8 Special properties of glyoxyl agarose support

Table 1

Some examples of enzymes stabilized by multipotent covalent immobilization of supports activated with glyoxyl groups

\begin{tabular}{lllll}
\hline & Source & $\begin{array}{l}\text { Recovered } \\
\text { activity (\%) }\end{array}$ & $\begin{array}{l}\text { Stabilization } \\
\text { factora }\end{array}$ & Reference \\
\hline Trypsin & Bovine pancreas & 75 & $10,000^{\mathrm{a}}$ & {$[24]$} \\
\hline Chymotrypsin & Bovine pancreas & 70 & $10,000^{\mathrm{a}}$ & {$[7]$} \\
\hline Penicillin G acylase & Escherichia coli & 70 & $8000^{\mathrm{a}}$ & {$[25]$} \\
\hline Penicillin G acylase & Kluyvera citrophila & 70 & $7000^{\mathrm{a}}$ & {$[26]$} \\
\hline Ferredoxin NADP reductase & Anabaena PCC7119 & 60 & $1000^{\mathrm{a}}$ & {$[27]$} \\
\hline Esterase & Bacillus & 70 & $1000^{\mathrm{a}}$ & {$[28]$} \\
\hline Gluarothermophilus & & & $1000^{\mathrm{a}}$ & {$[29]$} \\
\hline Formate dehydrogenase & Pseudomonas sp. 101 & 50 & $>5000^{\mathrm{a}}$ & {$[30]$} \\
\hline Alcohol dehydrogenase & Horse liver & 90 & $>3000$ & {$[31]$} \\
\hline
\end{tabular}

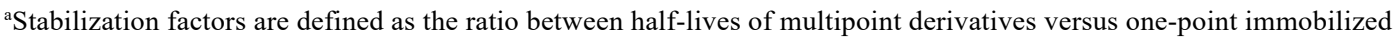
enzymes 
MULTIPOINT IMMOBILIZATION REQUIRES THE USE OF PH 10

SOME SOLUBLE ENZYMES ARE NOT STABLE AT pH $10,25^{\circ} \mathrm{C}$

SOLUTIONS:

- Immobilization of the enzyme at $4^{\circ} \mathrm{C}$

- Use of stabilizing inhibitors

- Use of stabilizing polyols (trehalose, glycerol, PEG, etc.)

- Use of stabilizing ions

Fig. 9 Handling of enzymes at $\mathrm{pH} 10$

As comment before, one-point immobilization could also promote interesting stabilizing effects because of the elimination of different causes of enzyme inactivation: aggregation, interaction with hydrophobic interphases. Therefore, 3D stabilization should be added to the stabilization by pure immobilization. The best derivatives could be millions of folds more stable than the corresponding soluble enzymes.

During the proposed immobilization process, some enzymes may be inactivated at alkaline $\mathrm{pH}$. In these cases, some inhibitors may be added to the immobilization buffer to protect the enzyme. Some ways to increase the stability of soluble enzymes at $\mathrm{pH} 10.0$ are summarized in Fig. 9.

Finally, some enzymes have a low amount of surface Lys residues and cannot be highly stabilized through this protocol. To overcome this problem, enzymes can be aminated by modification of carboxyl groups (asp and Glu residues) with etlylenediaminevia previous activation with $N$-(3-dimethyl-aminopropyl)- $N$-ethylcarbodiimide (EDAC) (See Notes I and 2). Examples of amination will be given in Methods [32, 33].

2 Materials

1. Cross-linked 10BCL and 6BCL agarose beads (Agarose Beads Technology, Madrid, Spain).

2. Glycidol (2,3-epoxy propanol) (Sigma-Aldrich S.A., St. Louise, MO, USA) (see Note 3).

3. $1.7 \mathrm{~N} \mathrm{NaOH}$ solution.

4. Sodium borohydride.

5. Support oxidation solution was $0.1 \mathrm{M}$ sodium periodate in water. 
6. Protein immobilization buffer consisted in $0.1 \mathrm{M}$ bicarbonate buffer at $\mathrm{pH} 10$.

7. Solution 1 for the monitoring and control of the oxidation: Prepare a solution of sodium periodate in distilled water in the same proportion as the suspension to be tested. This solution will be used as a blank.

8. Solution 2 for the monitoring and control of the oxidation: Prepare a solution of $1: 1(\mathrm{v}: \mathrm{v}) 10 \%$ potassium iodide and saturated sodium bicarbonate. This must be freshly prepared.

\section{Methods}

\subsection{Preparation of Glyoxyl Supports}

3.1.1 Activation of Agarose Gel to Glyceryl Agarose

\subsubsection{Oxidation of Glyceryl Agarose to Glyoxyl Agarose}

\subsubsection{Monitoring and} Control of the Oxidation
1. Wash $105 \mathrm{~g}(150 \mathrm{~mL})$ of commercial $6 \mathrm{BCL}$ or 10BCL agarose thoroughly with distilled water (see Note 4).

2. Suspend the agarose in distilled water up to a total volume of $180 \mathrm{~mL}$.

3. Add to this suspension $50 \mathrm{~mL}$ of $1.7 \mathrm{~N} \mathrm{NaOH}$ solution containing $3.4 \mathrm{~g}$ of sodium borohydride.

4. Take the vessel to an ice bath, keep the suspension gently stirred, and add dropwise $36 \mathrm{~mL}$ of glycidol (see Notes 4 and 5).

5. Keep the suspension under mild stirring overnight $(18 \mathrm{~h})$ at $25{ }^{0} \mathrm{C}$.

6. Filter and wash the support thoroughly with distilled water.

1. Resuspend $105 \mathrm{~g}$ of glyceryl agarose (prepared in Subheading 3.1.1) in 1.5 L of distilled water.

2. Add the proper amount of support oxidation solution slowly to this suspension while stirring (see Note 6).

3. Submit the suspension for gentle stirring for $2 \mathrm{~h}$.

4. Wash the support with an excess of distilled water and filter it to dryness.

5. Spectrophotometric assay. Fill the reference cuvette with $3 \mathrm{~mL}$ of solution 2. Fill the sample cuvette with $3 \mathrm{~mL}$ of solution 2 .

1. Prepare solution 1 (blank solution).

2. Prepare solution 2.

3. Spectrophotometric assay. Fill the reference cuvette with $3 \mathrm{~mL}$ of solution 2 . Fill the sample cuvette with $3 \mathrm{~mL}$ of solution 2 and add $0.2 \mathrm{~mL}$ of blank (solution 1). Measure the absor- bance at $419 \mathrm{~nm}$. 


\subsection{Enzyme Immobilization [34]}

4. Prepare a reference cuvette containing $3 \mathrm{~mL}$ of solution 2 . In the sample cuvette, place $3 \mathrm{~mL}$ of solution 2 . Then add $0.2 \mathrm{~mL}$ of supernatant of the suspension to be tested. Compare the absorbance at $419 \mathrm{~nm}$ with the one obtained in step 3 .

5. Repeat the assay with aliquots of supernatant withdrawn at different times until the reading is zero (all periodate has been consumed) or constant (no more periodate can be con- sumed because all groups have already been oxidized).

1. Incubate $10 \mathrm{~g}$ glyoxyl agarose with $100 \mathrm{~mL}$ of chemically aminated or nonmodified enzyme solution prepared in immobilization buffer.

2. Add $1 \mathrm{~mL}$ of distilled water to $9 \mathrm{~mL}$ of enzyme solution to be used as reference solution (see Note 7).

3. Gently stir the mixtures by end-over-end rotation at $25{ }^{\circ} \mathrm{C}$.

4. Aliquots of supernatant and suspension are withdrawn at regular time intervals (see Note 8) to assay enzyme activity.

5. Assay the activity of the reference solution using the same time intervals and aliquot volumes as in step 4 .

6. The immobilization process finishes when activity of the supernatant is zero.

7. Then, the immobilized preparation is washed five times with three volumes of immobilization buffer.

1. Resuspend the enzyme derivative (prepared in Subheading 3.3) in $100 \mathrm{~mL}$ of immobilization buffer.

2. Maintain the suspension for several hours (see Note 9). Although stirring is not necessary because the enzyme is already immobilized on the support, it is necessary to measure the activity of the suspension.

3. Add $100 \mathrm{mg}$ of solid sodium borohydride and stir the suspension for $30 \mathrm{~min}$ at $25^{\circ} \mathrm{C}$.

4. Finally, wash the enzyme derivative with $25 \mathrm{mM}$ sodiumphosphate $\mathrm{pH} 7.0$ while vacuum filtering to eliminate the borohydride.

5. Enzyme derivatives are stored at $4{ }^{\circ} \mathrm{C}$. 
3.4 Improving the

Stabilization of PGAby

Multipoint Covalent

Attachment on Glyoxyl

Supports Via Partial

Amination of the

Protein Surface

3.4.1 Enzyme Amination

3.4.2 Penicillin G Acylase Immobilization
1. $5 \mathrm{~mL}$ of soluble penicillin G acylase (PGA) from Escherichia coli was incubated with $45 \mathrm{~mL}$ of protein amination solution containing EDAC to a final concentration of $10^{-3} \mathrm{M}$. This protocol of amination allows the modification of $40-50 \%$ of the external carboxylic groups. This means that the modified enzyme has added to the 41 amines from the Lys, 12-14 of new amino groups generated via the amination. The modification presented negligible effect in the enzyme activity but decreased the stability of the enzyme (by a factor of eightfold).

However, as the full modification of PGA carboxylic groups caused a greater destabilization, the partial modification of the carboxylic groups with ethylenediamine (EDA) was chosen to carry out further studies.

1. $10 \mathrm{~g}$ of glyoxyl agarose 10BCL was added to $100 \mathrm{~mL}$ of aminated or nonmodified PGA solution $(0.55 \mathrm{mg}$ protein $/ \mathrm{mL})$ in sodium bicarbonate buffer $100 \mathrm{mM} \mathrm{pH} 9$ or 10 , con- taining $100 \mathrm{mM}$ phenylacetic acid and $20 \%$ glycerol [4]. The suspension was then gently stirred for $3 \mathrm{~h}$ at $\mathrm{pH} 10$ and $25{ }^{\circ} \mathrm{C}$ (see Notes 10 and II).

2. When immobilization was carried at $\mathrm{pH} 10$, full immobilization of PGA was observed within the first moments, using both not modified and aminated PGA. Residual activity was near $100 \%$ in both cases.

At $\mathrm{pH}$ 9, it was not possible to immobilize the nonmodified enzyme. Only the aminated enzyme could be rapidly and fully immobilized on the support. This fact could be explained because the $\mathrm{pK}$ value of $\varepsilon-\mathrm{NH}_{2}$ of external lysines is 10.7 , while the $\mathrm{p} K$ value of the artificially introduced primary amino groups is 9.2; therefore, they are even more reactive at $\mathrm{pH} 9$ than the superficial lysines at $\mathrm{pH} 10$.

3. The activity of both immobilized and soluble PGA was measured as follows: the initial reaction rates were measured using an automatic titrator (DL50 Mettler Toledo) to determine the amount of phenylacetic acid formed. The assays were carried out by adding aliquots of PGA to $10 \mathrm{~mL}$ of a $10 \mathrm{mM}$ penicillin $\mathrm{G}$ in $0.1 \mathrm{M}$ sodium phosphate $/ 0.5 \mathrm{M} \mathrm{NaCl}$ at $\mathrm{pH} 8$ and $25{ }^{\circ} \mathrm{C}$. The reaction mixture was titrated with $100 \mathrm{mM}$ $\mathrm{NaOH}$, kept at $25^{\circ} \mathrm{C}$ and mechanically stirred.

One International Unit(IU) of PGA activity was defined as the amount of enzyme that hydrolyzes $1 \mu \mathrm{mol}$ of penicillin $\mathrm{G}$ per minute at $\mathrm{pH} 8$ and $25{ }^{\circ} \mathrm{C}$. 
3.4.3 Structural Stabilization Via Multipoint Covalent Attachment
1. The aminated PGA immobilized on glyoxyl agarose at $\mathrm{pH} 10$ presented a half-life around two times higher than the unmodified immobilized PGA (that is 10,000-fold more stable than the one-point immobilized PGA) [4] (Fig. 2).

2. The stability of the derivatives immobilized at $\mathrm{pH} 9$ was lower than the ones immobilized at $\mathrm{pH} 10$. However, the stability was greatly improved if after immobilization at $\mathrm{pH} \mathrm{9,} \mathrm{the} \mathrm{pH}$ value was increased to $\mathrm{pH} 10$ to favor the reaction of the lysines of the protein surface with the aldehyde groups on the support. This derivative was found to be around a twofold factor more stable than the aminated PGA directly immobilized at $\mathrm{pH} 10$ (Fig. 3). At $\mathrm{pH} 10$, the enzyme is immobilized by the region/ $\mathrm{s}$ with the highest density of lysines plus primary amino groups introduced by the chemical modification, while at $\mathrm{pH}$ 9, the immobilization proceeds through the area with the highest density of primary amino groups introduced by chemical mod- ification. This difference permits a higher number of enzyme support linkage and/or to the implication of a region in the immobilization involved in the inactivation of the enzyme.

4 Notes

1. It has been described that the use of $0.1 \mathrm{M}$ EDA at $\mathrm{pH} 4.75$ and $10 \mathrm{mM}$ EDAC allows the full modification of the carbox-ylic groups of the protein surface, while using $1 \mathrm{mM}$ EDAC in $1 \mathrm{M}$ EDTA at $\mathrm{pH} 4.75$ the modification degree is only around 40 $50 \%$ [33].

2. The choice of the amount of EDAC to be used is done by evaluating its impact on the activity and stability of the previously immobilized enzyme. Thus, modification conditions which decrease the stability of the modified enzymes are avoided [22].

3. Store between 0 and $5{ }^{\circ} \mathrm{C}$ (toxic).

4. Avoid magnetic stirring of agarose, especially during long reaction times.

5. Glycidol addition must be very slowly to prevent the temperature rising over $25{ }^{\circ} \mathrm{C}$.

6. Oxidation of glycols with sodium periodate is a stoichiometric reaction. Therefore, the activation degree of the support can be easily controlled through the periodate concentration used. The protocol described allows for obtaining an activation degree of 75 and $200 \mu \mathrm{mol} / \mathrm{mL}$, and for this, 112.5 and $300 \mathrm{~mL}$ of oxidation solution have to be added to completely oxidize 6BCL and 10BCL agarose, respectively. 
Calculation of volume of $0.1 \mathrm{M}$ sodium periodate for a degree of activation of $N \mu \mathrm{mol} / \mathrm{mL}$ :

$$
100 \mathrm{~mL} \text { agarose } \times N \frac{\mu \mathrm{mol}}{\mathrm{mL}} 1 / 4 \mathrm{X} \text { total } \mu \mathrm{mol}
$$

$\frac{X}{100} \mathrm{mM}$ sodium periodate $1 / 4 \mathrm{YL} 0: 1 \mathrm{M}$ sodium periodate

Ratio gel : suspension (v:v) $1 / 41: 10$

$1000 \mathrm{~mL} 1 / 4$ total volume of suspension

$1000 \mathrm{~mL}$ - $100 \mathrm{~mL}$ agarose $-Y \mathrm{~mL}$ sodium periodateP

$1 / 4 Z \mathrm{~mL}$ distilled water

7. If the enzyme activity decreases during the course of immobilization due to enzyme inactivation, this effect must be distinguished from loss of the supernatant resulting from immobilization.

8. The supernatant was obtained by pipette filter or by centrifugation of the suspension.

9. Rigidification of the protein structure via the formation of multipoint covalent linkages between its nonionic amine groups and the reactive groups of the support could be obtained by keeping the suspension at $\mathrm{pH} 10$ for a fairly long interaction time at $25{ }^{0} \mathrm{C}$. The optimum multi-interaction time is the shortest one that provides the maximal stability of the enzyme derivative.

10. The already immobilized enzymes were incubated under the conditions reported to yield the maximum stability for the nonmodified enzyme [4].

11. Commercial preparation of PGA (Roche, Basel, Switzerland) was diluted fivefold $(\mathrm{v} / \mathrm{v})$ in $25 \mathrm{mM}$ potassium phosphate buffer $\mathrm{pH} 7.0$ and then dialyzed threefold against 100 volumes of $25 \mathrm{mM}$ potassium phosphate buffer $\mathrm{pH}$ 7.0. The dialyzed enzyme was then centrifuged (6182 gin a rotor JA-25.5) and the supernatant (containing $16 \mathrm{IU} / \mathrm{mL}$ and $11 \mathrm{mg}$ of protein $/ \mathrm{mL}$ ) was used as the enzymatic preparation for further experiments. More than $90 \%$ of initial activity was recovered after this process. 
References

1. Haki GD, Rakshit SK (2003) Developments in industrially important thermostable enzymes: a review. Bioresour Technol 89:17-34

2. Wong SS, Wong LJ (1992) Chemical crosslinking and the stabilization of proteins and enzymes. Enzym Microb Technol 14:866-874

3. Klibanov AM (1983) Immobilized enzymes against termal inactivation. Adv Appl Microbiol 29:1-28

4. Alvaro G, Fernández-Lafuente R, Blanco RM, Guisán JM (1990) Immobilization- stabilization of penicillin acylase from E. coli. Appl Biochem Biotechnol 26:181-195

5. Guisán JM, Alvaro G, Fernández-Lafuente R, Rosell CM, Garcia-Lopez JL, Tagliatti A (1993) Stabilization of a heterodymeric enzyme by multi-point covalent immobiliza- tion: penicillin $\mathrm{G}$ acylase from Kluyvera citro- phila. Biotechnol Bioeng 42:455-464

6. Blanco RM, Guisán JM (1988) Protecting effect of competitive inhibitors during very intense insolubilized enzyme-activated support multipoint attachments: trypsin (amine)agarose (aldehyde) system. Enzym Microb Technol 10:227-232

7. Guisán JM, Bastida A, Cuesta AC, FernándezLafuente R, Rosell CM (1991) Immobilizationstabilization of chymotrypsin by covalent attachment to aldehyde agarose gels. Biotechnol Bioeng 39:75-84

8. Tardioli PW, Pedroche J, Giordano RL, Fernández-Lafuente R, Guisán JM (2003) Hydrolysis of proteins by immobilized-stabilized alcalase $₫$-glyoxyl agarose. Biotechnol Prog 19:352-360

9. Pedroche J, Yust MM, Girón-Calle J, Vioque J, Alaiz M, Mateo C, Guisán JM, Millán F (2002) Stabilization-immobilization of carboxypeptidase to aldehyde-agarose gels. A practical example in the hydrolysis of casein. Enzym Microb Technol 31:711-718

10. Tardioli PW, Fernández-Lafuente R, Guisán JM, Giordano RLC (2003) Design of new immobilized-stabilized carboxypeptidase a derivative for production of aromatic free hydrolysates of proteins. Biotechnol Prog 19:565-574

11. Bes T, Gomez-Moreno C, Guisán JM, Fernández-Lafuente R (1995) Selective enzy-metic oxidations: stabilization by multipointcovalent attachment of ferredoxin NAD- reductasa: an interesting cofactor recycling enzyme. J Mol Catal 98:161-169

12. Guisán JM, Polo E, Agudo J, Romero MD, Alvaro G, Guerra MJ (1997) Immobilizationstabilization of thermolysin onto activated agarose gels. Biocatal Biotransformation 15:159-173

13. Betancor L, Hidalgo A, Fernández-Lorente G, Mateo C, Rodríguez V, Fuentes M, FernándezLafuente R, Guisán JM (2003) The use of physicochemical tools to solve enzyme stability problems alters the choice of the optimal enzyme: stabilization of $D$-aminoacid oxidase. Biotechnol Prog 19:784-788

14. Betancor L, Hidalgo A, Fernández-Lorente G, Mateo C, Rodríguez V, Fuentes M, FernándezLafuente R, Guisán JM (2003) Preparation of a stable biocatalyst of bovine liver catalase. Biotechnol Prog 19:763-767

15. Hidalgo A, Betancor L, Lopez-Gallego F, Moreno R, Berenguer J, FernándezLafuente R, Guisán JM (2003) Preparation of a versatile biocatalyst of immobilized and stabilized catalase from Thermus thermophilus. Enzym Microb Technol 33:278-285

16. Otero C, Ballesteros A, Guisán JM (1991) Immobilization/stabilization of lipase from Candida rugosa. Appl Biochem Biotechnol 19:163-175

17. Suh C-W, Choi G-S, Lee E-K (2003) Enzymatic cleavage of fusion protein using immobilized urokinase covalently conjugated to glyoxyl-agarose. Biotechnol Appl Biochem 37:149-155

18. Toogood HS, Taylor IN, Brown RC, Taylor SJC, McCague R, Littlechild JA (2002) Immobilisation of the thermostable L-aminoacylase from Thermus litotalis to generate a reusable industrial biocatalyst. Biocatal Biotransformation 20:241-249

19. Ichikawa S, Takano K, Kuroiwa T, Hiruta O, Sato S, Mukataka S (2002) Immobilization and stabilization of chitosanase by multipoint attachment to agar gel support. J Biosci Bioeng 93:201-206

20. Kuroiwa T, Ichikawa $S$, Sato $S$, Mukataka $S$ (2003) Improvement of the yield of physiologically active oligosaccharides in continuous hydrolysis of chitosan using immobilized chitosanases. Biotechnol Bioeng 84:121-127

21. Kuroiwa T, Ichikawa S, Sosaku H, Sato S, Mukataka S (2002) Factors affecting the composition of oligosaccharides produced in chitosan hydrolysis using immobilized chitosanases. Biotechnol Prog 18:969-974

22. Mateo C, Abian O, Bernedo M, Cuenca E, Fuentes M, Fernandez-Lorente G, Palomo JM, Grazu V, Pessela BCC, Giacomini C, Irazoqui G, Villarino A, Ovsejevi K, Batista- Viera F, Fernandez-Lafuente R, Guisán JM (2005) Some special features of glyoxyl 
supports to immobilize proteins. Enzym Microb Technol 34:456-462

23. Mateo C, Abian O, Fernandez-Lafuente R, Guisan JM (2000) Increase in conformational stability of enzymes immobilized on epoxy- activated supports by favouring additional mul- tipoint covalent attachment. Enzym Microb Technol 26:509-515

24. Blanco RM, Guisán JM (1988) Stabilization of enzymes by multipoint covalent attachment to agarosealdehyde gels. Borohydride reduction of trypsin-agarose derivatives. Enzym Microb Technol 11:360-366

25. Alvaro G, Blanco RM, Fernández-Lafuente R, Guisán JM (1990) Immobilization- stabilization of penicillin G acylase from E. Appl Biochem Biotechnol 26:210-214

26. Guisán JM, Alvaro G, Fernández-Lafuente R, Guisán JM (1993) Stabilization of a heterody- meric enzyme by multi-point covalent immo- bilization: penicillin G acylase from Kluyvera citrophila. Biotechnol Bioeng 42:455-464

27. Bes T, Gomez-Moreno C, Guisán JM, Fernán- dez-Lafuente R (1995) Selective enzymetic oxidations: stabilization by multipoint covalent attachment of ferredoxin NAD-reductasa: an interesting cofactor recycling enzyme. J Mol Catal 98:161-169

28. Fernández-Lafuente R, Cowan DA, Wood ANP (1995) Hyperstabilization of a thermo- philic esterase by multipoint covalent attach- ment. Enzym Microb Technol 17 (1995):366-372

29. Mansur M, Garcia JL, Guisán JM, Garcia- Calvo E (1998) Cloning, expression and immobilization of glutamate racemase from Lactobacillus fermenti for the production of $D$-glutamate from $L$-glutamate. Biotechnol Lett 20:57-61

30. Bolivar JM, Wilson L, Ferrarotti SA, Fernandez-Lafuente R, Guisan JM, Mateo C (2006) Stabilization of a formate dehydroge- nase by covalent immobilization on highly acti- vated glyoxyl-agarose supports. Biomacromolecules 7:669-673

31. Bolivar JM, Wilson L, Ferrarotti SA, Guisán JM, Fernández-Lafuente R, Mateo C (2006) Improvement of the stability of alcohol dehy- drogenase by covalent immobilization on glyoxyl-agarose. J Biotechnol 125:85-94

32. Abian O, Grazú V, Hermoso J, González R, García JL, Fernández-Lafuente R, Guisán JM (2004) Stabilization of penicillin $\mathrm{G}$ acylase from Escherichia coli: site-directed mutagenesis of the protein surface to increase multipoint covalent attachment. Appl Environ Microbiol 70:1249-1251

33. López-Gallego F, Montes T, Fuentes M, Alonso N, Grazu V, Betancor L, Guisan JM (2005) Chemical increase of the amount of reactive groups on enzyme surface to improve its stabilization via multipoint covalent attach- ment. J Biotechnol 116:1-10

34. Guisan JM (1988) Agarose-aldehyde gels as supports for immobilization-stabilization of enzymes. Enzym Microb Technol 10:375-382 
